\title{
What Is the Public Role of the University? A Proposal for a Public Research Agenda
}

\author{
GERT BIESTA \\ Stirling Institute of Education, University of Stirling, United Kingdom \\ MAREK KWIEK \\ Centre for Public Policy, Poznan University, Poland \\ GRAHAME LOCK \\ Radboud University Nijmegen, Netherlands; Leiden University, Netherlands; \\ University of Oxford, United Kingdom \\ HERMÍNIO MARTINS \\ University of Oxford, United Kingdom; University of Lisbon, Portugal \\ JAN MASSCHELEIN \\ Centre for Philosophy of Education, Catholic University of Leuven, Belgium \\ VASSILIKI PAPATSIBA \\ School of Education, University of Sheffield, United Kingdom \\ MAARTEN SIMONS \\ Centre for Educational Policy and Innovation/ \\ Centre for Philosophy of Education, Catholic University of Leuven, Belgium \\ PAVEL ZGAGA ${ }^{[1]}$ \\ Centre for Educational Policy Studies, Faculty of Education, \\ University of Ljubljana, Slovenia
}

\section{Introduction}

With a view to meeting the demands of the knowledge economy and taking up a leading role in its further development, Europe and its member states are urging universities and institutions for higher education more generally to innovate and modernise themselves. Organisational structures, governance and management systems, curricula and teaching methods, and funding and incentives mechanisms are no longer considered to be adequate to guarantee that European universities can keep up with global competition in education, research and innovation. Innovation and modernisation are also considered to be necessary with regard to the public (i.e. social, cultural and political) role of universities. Today's knowledge-intensive economies and societies are regarded as in need of up-to-date policies on equal opportunities, participation and access, and of strategies for knowledge-driven local and regional economic, social and cultural development. In addition to this and based on a concern about European citizenship, democratic involvement and social cohesion, there is a requirement for the development of curricula, extra-curricular activities and participation structures that offer students opportunities to develop civic competencies.

The contributions to this special issue have not only pointed at problems with the particular shape and form of the modernisation agenda of European higher education, but have also indicated alternative ways in which European universities might articulate their public role, not through the 
simple 'production' of a particular kind of active citizen, but by creating opportunities where things can be made public and can become a matter of public concern, and where publics can constitute themselves around such issues. This not only hints at a very different articulation of the public role of the university, but also suggests a different articulation of active citizenship. The contributions to this special issue thus provide starting points for the development of an alternative agenda for the future of European higher education. If the future of European higher education is in itself a matter for public concern, then the development of such an agenda is too important to be left in the hands of experts and policy makers. In what follows we present an outline of a possible public research agenda on the public role of the university and an invitation to join in the further development of this agenda. All people affected (or not) by the university are invited to give a public voice regarding the university's public role, taking as a point of departure the practices, initiatives and projects they are actually involved in (or prevented from being involved in).

The point of departure for this agenda is the question: What do universities actually have to offer regarding their public role?

\section{From an Innovation Agenda}

In 2006, the Commission of the European Communities published the communication Delivering on the Modernisation Agenda for Universities: education, research and innovation. The communication proposes a 'modernisation agenda' based on the diagnosis that 'European universities are not currently in a position to achieve their potential in a number of important ways':

As a result, they are behind in the increased international competition for talented academics and students, and miss out on fast changing research agendas and on generating the critical mass, excellence and flexibility necessary to succeed. These failures are compounded by a combination of excessive public control coupled with insufficient funding. (Commission of the European Communities, 2006, p. 4)

With a view to establishing some 'world-renowned research institutions' (Commission of the European Communities, 2006, p. 4) that can compete with the best in the world, the main strategy of the delivered agenda is differentiation: research-intensive institutions next to excellent universities and colleges working on a regional or national scale building upon their own particular strengths (see the contributions of Simons \& Masschelein, Masschelein \& Simons, and Kwiek in this issue).

The urgent call to modernise universities - 'not only as a core condition for the success of the broader Lisbon strategy, but also as part of the wider move towards an increasingly global and knowledge-based economy' (Commission of the European Communities, 2006, p. 1) - embraces specific initiatives: increased mobility of graduates and researchers; new internal governance systems with a view to strategic management; incentives for partnerships with the business community; enhancing the employability of graduates by providing the competencies and skills needed by the labour market; reducing the funding gap (at least $2 \%$ of gross domestic product) and making funding more effective (for instance, based on outputs instead of inputs); enhancing interdisciplinarity and transdisciplinarity (taking research domains as a point of departure instead of research disciplines); activating knowledge based on interactions with stakeholders; rewarding excellence at the highest level (and in order to attract the best academics and researchers); and making the European Higher Education Area and European Research Area more visible and attractive (Commission of the European Communities, 2006, pp. 5-10).

The suggested initiatives of the modernisation agenda clearly have a particular scope and aim: an optimal mobilisation of available resources if Europe is not to lose out in the global competition in education, research and innovation' (Commission of the European Communities, 2006, p. 11). Underlying this there is no longer a political and administrative perspective seeking to govern a 'European higher education system' enclosing different institutions, but a managerial attitude in search of innovation strategies to adapt the 'higher education and university enterprise' to a competitive environment. From this managerial viewpoint - that is, the efficient and effective production of research, teaching and innovation - dismantling institutions, restructuring organisational units, introducing incentive systems and relocating human resources appear as necessary options. Although less centrally managed, the Bologna project in its focus on, for 
instance, the mobility of students and lecturers, and comparability regarding degrees, programmes and quality assurance systems embraces a similar rationale (see the contributions of Zgaga and Lock \& Martins in this issue).

The optimal mobilisation of resources also seems to be the basic aim in order to 'reinforce the societal roles of universities' (Commission of the European Communities, 2006, p. 2). One strategy that is deployed is to seek ways to mobilise curricular and extra-curricular resources in such a way that young people have optimal opportunities to acquire civic competencies. It is assumed in this strategy that universities become one more socialising agent for the production of the competent active citizen. The point of departure is that citizenship is an individual competence-based identity (rather than a public identity), that developing citizenship is about functionally inserting individuals into the existing social and political order (reproduction rather than confrontation with plurality and difference) and that democracy is a consensus procedure (rather than a site for political and social contestation) (see the contributions of Biesta and Papatsiba in this issue). The 'active citizenship' agenda is once more a mobilisation agenda that forces universities to meet the demands which the current knowledge society holds for them.

Taking into account the agenda's scope, 'innovation agenda' is perhaps a more appropriate term for the underlying rationale. While 'modernisation' suggests profound changes with a view to meeting the challenges and characteristics of the present, 'innovation' is about changes in search of competitive advantage or restructuring with a view to more efficient, effective or a new use of available resources (see the contribution of Simons \& Masschelein in this issue). Taking the current competitive environment as a given, Europe and its member states indeed have no hesitations about the private and public functions universities have to assume. Their main concern is how to innovate the existing governance structures and organisations, and how to mobilise available human, physical and financial resources in order to meet these private and public ends. A countermove is necessary at this point.

\section{Towards a Public Research Agenda}

It is necessary to slow down the current mobilisation agenda by putting forward the question of what universities, as universities, actually have to offer Europe and its member states. The point of departure for this question is that universities, and their specific mission, could have something unique to offer. A debate on what that is, or may be, is not part of the current innovation agenda. The opposite seems to be the case. Although it is acknowledged that the university's specificity as an institution resides in its combination of three tasks (research, teaching and service), indirectly it undermines this specificity through the suggested strategy of further differentiation regarding these tasks. Why, then, still rely upon institutions that are called universities if each of the university's functions is perhaps being performed more efficiently by monofunctional institutions? Why not dismantle those institutions and support private enterprises that are more responsive to the needs of a highly competitive knowledge economy?

The possibility of raising these questions could itself be regarded as an indication that universities have difficulties in defining their uniqueness and, as a result, these questions could be embraced as an additional justification for the suggested innovation agenda. However, and as outlined in the contributions to this special issue, these questions can also be approached in another way. They can be approached as an indication of what to look at when discussing the role of the university and what it has to offer. Indeed, the point of departure is that the university's role is related to the unique combination of tasks, and particularly the public dimension of these tasks and their combination. Therefore, the following question is put forward: What is the public role of universities, and what is their public role regarding teaching, research and service? Or, put another way, and addressing their public role more directly: How are universities, relying on their specific role, committed to a critical and political form of (European) citizenship?

In order to address this question, we wish to propose the development of a counter-agenda or at least a complementary agenda. However, the question does not ask for a policy-driven innovation agenda, but for a public-oriented research agenda. In order to be able to answer the question, things have to be explored, investigated, studied, proposed and discussed by all those who are somehow affected. The assumption is that, despite the university becoming a competitive 
environment calling for an entrepreneurial attitude, many people still embrace some sort of 'public ethos'. It is assumed that people still seek to promote public dimensions in their learning, teaching, research and policy making, and that they do this through specific, locally embedded and often experimental practices and projects. Yet, what is being done is often taken for granted, ill-defined or lacking legitimacy or seriousness in the current innovation discourses. Precisely for this reason, it is our contention that there needs to be a public voice and further investigation and debate on what is actually being done.

However, instead of asking experts to find out what is currently happening (and what should be on the research agenda), we want to give a voice to those who are actually working in the university or to people who are in one way or another affected by it (or are seeking to become affected by it). We wish to invite them to turn the issues they are dealing with in their daily, local and often hidden lives into a public concern; transforming what is actually going on into a public issue - that is, an issue around which a public can gather and which can be explored and debated. The aim of this agenda is to gather people around the question 'What is the public role of the university?' and to try to transform this question again into a matter of public concern (preventing it from being reduced to a problem that experts or policy makers have to find a solution for).

All interested people who are part of the university or somehow affected by it (or not [yet] affected by it) are invited to investigate what they are actually doing (and/or are prevented from doing) and to give it a public voice. In view of the question 'What is the public role of the university?', not only students and academics, but also staff members, deans, rectors and publishers are invited to examine their learning, teaching, research, development and governing. The aim, however, is not in the first instance 'to collect and spread good practices' or 'to share experiences', but to give a public voice to what people are actually doing or being prevented from doing.

There is clearly no single way to raise a public voice, but there are, perhaps, some basic ingredients: a thorough investigation of what one is doing (for example, in research, teaching or service, in policy making, publishing or learning); an exploration of the broader institutional and cultural, economic and political context; a discussion of the opportunities and limits within that context; and, foremost, an articulation of the conception of the 'public role of the university' that one embraces. Although finding a more precise definition of 'public' is part of the research agenda, we suggest the following minimal definition: 'public' refers to what exceeds the interests of a particular individual or group, and for that reason turns it into a concern for 'the public' and turns a group of individuals into a public for the concern (see the contribution of Simons \& Masschelein in this issue).

The following topics, listed in separate categories only for the sake of clarity, can be addressed:

\section{Research and Its Public}

- Which forms of research, both at the level of the process and output/orientation, have a distinctive public scope?

- What is a distinctive public research ethos and concern, and how is it connected to teaching and service?

- What kind of selection and evaluation practices, application procedures, forms of communication and publication, organisational/electronic and architectural infrastructures support public research?

- What governance and financial structures support public research? What is the role of the (European, national, local) government in supporting this kind of research?

- What strategies, organisational structures, forms of regulation and attitudes prevent or limit public research? Or, conversely, what strategies, structures, regulations and attitudes turn research into a private enterprise?

\section{Education and Its Public}

- What forms and practices of education, at the level of access, process and results, have a distinctive public scope? 
- What is a distinctive public teaching and (lifelong) learning ethos and concern, and how is it connected to research and service?

- What kind of educational, teaching and evaluation/assessment practices and procedures, curriculum settings, communication and study tools, and organisational/electronic and architectural infrastructures support public education?

- What governance and financial structures support public education? What is the role of the (European, national, local) government in supporting this kind of education?

- What strategies, organisational structures, forms of regulation and attitudes prevent or limit public education? Or, conversely, what strategies, structures, regulations and attitudes turn education into a private enterprise?

\section{Service/Innovation and Its Public}

- What forms of service, partnerships with the local community, region and actors in the global context, political, cultural, social and economic projects, and additional research/teaching initiatives have a distinctive public scope?

- What is a distinctive public service ethos, and how is it connected to teaching and research?

- What forms of collaboration, participation, political contestation and deliberation support public service initiatives?

- What forms and strategies of communication and publication support the public role?

- What governance and financial structures, evaluation practices and procedures support public service? What is the role of the (European, national, local) government in supporting this kind of service?

- What strategies, organisational structures, forms of regulation and attitudes prevent or limit public service? Or, conversely, what strategies, structures, regulations and attitudes turn service into a private enterprise?

\section{University Work and Life, and Its Public}

- What kinds of working, learning and study conditions articulate or support the public role of the university?

- What kinds of housing and eating facilities articulate or support the public role of the university?

- What kinds of social, cultural or political gatherings and activities have a distinctive public dimension?

- What governance and financial structures support the public dimension of university work and life? What is the role of the (European, national, local) government at this point?

- What strategies, organisational structures, forms of regulation and attitudes prevent or limit university work and life from having a public dimension?

\section{And towards a Possible Modernisation Agenda}

Does a public research agenda have any relevance or impact? It is difficult to answer this question as this project itself is a kind of (collective) experiment. However, and in conclusion, it is maybe more important to discuss at what level we seek influence. It is clearly not our aim to translate the research agenda on 'What do universities have to offer?' into additional strategies for restructuring and innovation that look for competitive advantages and optimal resource mobilisation and allocation. Rather than an additional managerial innovation agenda, the proposed agenda is, perhaps, a first step towards a genuine modernisation agenda.

If modernisation is, indeed, about changing one's mindset with a view to what is actually of importance, and facing the present fully aware of the consequences of one's actions, perhaps this initiative can become part of a modernisation agenda. Modernisation, then, is less about innovative development, competitive self-improvement and entrepreneurial skills and more about an experimental ethos, searching for new ways of looking and thinking, and raising new voices. And, perhaps, it is foremost about having the courage to slow down current processes of mobilisation in 
order to think and rethink in the face of the present and the future it holds for us. Part of a modernisation agenda is transforming the European university from being a managerial concern to a public concern - that is, gathering people around the university as an issue that needs public investigation, contestation and deliberation. Perhaps this project on 'the university and its public' then could become 'on the public and its university'.

As part of the development of the agenda, the contributors to this special issue will be organising the symposium 'The University and Its Public: towards a different agenda for the public role of the European university' in December 2010, in Leuven, Belgium. A Call for Papers and other kinds of contributions/initiatives that discuss the university's public role will be distributed in September 2009. For suggestions or questions, contact: maarten.simons@ped.kuleuven.be

\section{Note}

[1] Alphabetic order, and with special thanks to the Catholic University of Leuven/Radboud University Nijmegen Covenant for its financial support of this initiative.

\section{Reference}

Commission of the European Communities (2006) Delivering on the Modernisation Agenda for Universities: education, research and innovation. Communication from the Commission to the Council and the European Parliament, COM(2006) 208 final, 10 May. Brussels: Commission of the European Communities. 